\title{
Patronage Leadership in Decentralized Developing Countries
}

\author{
Mochamad Doddy Syahirul Alam \\ Faculty of Administrative Science \\ University of Brawijaya \\ Malang, Indonesia \\ doddyfisip@gmail.com
}

\author{
Sujarwoto \\ Faculty of Administrative Science \\ University of Brawijaya \\ Malang, Indonesia \\ sujarwoto@ub.ac.id
}

\begin{abstract}
Some decentralized developing countries in Asia and Africa have the same problem on patronage leadership. The same of historical story could be influenced of the matter. Mostly the patronage happens in political leadership and business leadership. The actor represents government leadership and business leadership. If the cooperation and collaboration between government and business sector run by the regulation, it will emerge good governance. But in fact, they are tending to break the law and doing corruption. This paper aims to identify and to explain the practical patronage leadership in political and business field particularly in decentralized developing countries. Even this paper doing by literature review, hopely it can perform clearly about patronage leadership.
\end{abstract}

Keywords-patronage; leadership; political; business; decentralized developing countries

\section{INTRODUCTION}

It has been long time ago patronage leadership was existed and related with corruption practice in many affairs. There was no indigenous pattern of patronage leadership and corruption happening in government performance tier. The study of patronage, leadership, corruption, and decentralization usually did in separated framework. Therefore, the content usually tends to general understanding, not specific one. This study tries to contributes to our understanding of patronage leadership and corruption in decentralized developing countries on holistic understanding.

Patronage also explains organized corruption in strong states. It vests arbitrary power in the hands of unaccountable appointees who emerge from and disappear back into 'a secret world in which corruption can be practiced with impunity [1]. It encourages particularism in organizations, generating adverse effects on behavior including distrust, shirking, and poor organizational commitment [1]. In these and other ways, patronage undermines attempts to reform organizations and governments and to improve the lives of the poor and disadvantaged [1]. It disrupts formal politics at both national and local scales [1]. It breaks up horizontal connections, disorganizes people and perpetuates inequality and dependency [1]. And it interferes with fair and impartial management of the economy and, as in the Ukraine, increases the risk of financial crises the collapse of the state [2]. In Africa, too, post-colonial rulers more often than not bought loyalty by redistributing resources and assets as patronage. This was effective in building power bases initially; but it soon meant that less was available for wider population; and it eroded the organizations through which those goods and services were supplied. As these channels withered, rulers begin to rely more and more on parceling out economic opportunities and markets to their loyal supporters through local leaders. These leaders bought up support from those people who might otherwise have participated in reformist movements, and marginalized others with more overt ideological agendas. In this way, local networks were strengthened at the expense of the ruler whose own networks of patronage weakened and eventually collapsed, and formal organizations were replaced with political networks rooted in pervasive and predatory commercial activities [1]; [2].

According to the influential theory of Martin Shefter, patronage politics results from the capture of the state for the purposes of party building by political intermediaries. This will occur where democratization precedes professionalization of the bureaucracy and mass mobilization by political parties. By design, this theory only addresses the issue of patronage in democratic states. [3]

Moreover, we talk about the arrangement of patronage into organizations and organizational patterns with democratic or democratic-like features (such as forum or debates or processes to share power or rotate the leadership). These are pragmatic responses to tensions generated amongst competing groups, each vying for influence. One small, though significant, illustration of an organization shaped from patronage is the search committee which aids the president of the Philippines in the selection of political appointees at the highest level. The body is not a constitutional requirement but thrown up in response to the many interest groups fielding their own favored candidates for high-level posts. It has appeared and dissolved with each administration since the mid 1980s and exhibits both formal and informal modes of operation. Much the same can be said of the Commission on Appointments. Although constitutional discipline gives it permanence, it has an energy that pulses with the rise and fall of administrations. In both organizations, it is as favors given and taken as part of relationship that information and 
assessments of appointees are transmitted and approaches to candidates and deals on appointments are made. It is also worth noting that groups of patrons and their respective clients are also found within private businesses. Kondo, for instance, describes the head of Philippine corporations' close elite groups who encourage competition and monitoring amongst their clients at subordinate levels [1].

Viewed as an aspect of social relationship, the role of patronage in the emergence of formal organizations and democratic patterns is not hard to appreciate. The fundamentally reciprocal nature of what is classed as patronage; its emotional layering; the dependency of patrons on their clients; the clients' willingness and ability to control, weaken and dismiss their patrons; the need for programmaticstyle policies especially as the density of patrons increases and competition among them for clients intensifies; the arrangement of relationships (in which patronage is an important aspect) into organizations and rotate leadership [1].

In Timor Leste, patronage-based government is necessary if political instability and violence are to be prevented [1]. Chabal and Daloz make a similar point, arguing in Africa-where informality, patronage and clientelism networks are everything and determine access to resources and influence-western institutional models are of little relevance and the notion of a Bayert's 'rhizome state' more apt [1]. In China, too, 'phenomenon such as corruption, gift giving, and patron-client relationship, which are part of the sphere of personal transactions, play a pivotal role in mediating the transactions between market and bureaucracy and in integrating society at the level of social action [1]. The result is a new type of social formation- 'capital socialism'. Patronage was also a persistent feature in the evolution of government in Europe and America, and is to be found in modern states. In the UK in the 1970s British ministers were responsible for some 10,000 politically selected appointees (matching the number thought to be at the disposal of the Philippine president); and during the 1980s and 1990 both Labor and Conservative parties continued with 'clientelistic practices whereby public-sector appointees were distributed as a means of maintain and rewarding political or electoral support [1].

\section{RESEARCH METHOD}

To examine patronage leadership in decentralized countries, I assembled from various sources. The data collected by searching from some journals such as Proquest, emerald, and also google scholar for last five years later. I had downloaded and reviewed not less than thirty paper/articles. The methodological principles upon which this study was developed are influenced by systematic reviewing techniques [4] and include seeking transparent and rigorous approaches to identification, quality appraisal and synthesis of studies. At its simplest, systematic reviews are "designed to provide a reliable picture of 'current best evidence' relevant to a particular question" [5]. While great emphasis is placed on the rigor of selection and appraisal methods within such reviews, of equal importance is the methodical quality of data synthesis [6]. Campbell et al. [7] describe 'synthesis' as "a process of extracting data from individual research studies and interpreting and representing them in a collective form".
Table 1. Number of sources

\begin{tabular}{|l|c|c|}
\hline \multicolumn{1}{|c|}{ Sources } & Number of articles & $\begin{array}{c}\text { Selected } \\
\text { articles }\end{array}$ \\
\hline Google Scholar & 50 & 15 \\
\hline ProQuest & 40 & 10 \\
\hline Emerald & 20 & 5 \\
\hline Scopus & 10 & 3 \\
\hline N & 120 & 33 \\
\hline
\end{tabular}

\section{RESULT AND DISCUSSION}

\section{A. Political Patronage Leadership}

Politics and leadership are two points that always related one each other particularly governmental affair and political affair. In some decentralized developing countries political patronage leadership use some channels there are political party, elite capture, and non-elite capture community. Scott (1969) define that patronage polities is what matters most to the operation of patronage politics is political control over the implementation of government policy. Although in relatively programmatic states of the West where politicians worry about the design of public policy and Weberian bureaucratic impartially implement this policy as directed, in patronage politics takes place at the level of implementation [8].

In Indonesia, elite control and elite capture have to be understood in the context of what one member of the village elite described as the "intertwining circles of leadership, family and money" so evident in Bandar Agung village (interview with AR, 8.04.2011). Because of the extraordinary stranglehold of particular political patronage relationships in Bandar Agung, both members of the elite who were outside the group controlling project funds and non-elite community members felt themselves powerless to affect the abuse of authority in Bandar Agung [11]. Elite capture has been facilitated by decentralization policies in Indonesia which gave local elites increased access to resources, and paradoxically by the role of the political party system that has emerged since the end of authoritarian rule in 1998, although this has been more evident in studies at district than at village level [2]. In some cases, it is possible to track the direct connection between elite capture of resources through official positions and corruption [8].

As the same as Indonesia, Bangladesh have democratic transition and political patronage still extend and coloring the governmental affair. Despite large amounts of aid, the World Bank and Western donors argue that poor governance and weak institutions in Bangladesh have acted as significant constraints on development. The fundamental dilemma faced by the donor, however, is whether foreignfunded institutional and technical fixes can genuinely address problems of governance that are deeply rooted in the country's historical experience and the behavior and values of the Bangladesh elite [9].

Another case in Africa, state resources in Zimbabwe are allocated along party lines. Food has also been used as political tool by the Mugabe administration by excluding 
opposition supporters from receiving food aid from the government. It is as if the food is coming from party coffers and not state institutions.

Mugabe has also stayed in power for too long by controlling the security structures and also the media. Licenses were also given to pro-Mugabe supporters and clients-patron-client network. Repressive legislation, the Access to Information Protection and Privacy Act (AIPPA) and the Public Order Security Act (POSA) entrenched intimidation, and tightened the hold of the ruling party over state mechanisms of arrest, incarceration, violence and control of populations and resources. The laws criminalize citizens for criticizing the office of the Presidency. Mlambo [10] aptly sheds light on the Zimbabwean situation since the turn of the millennium

Poverty in India presents an interesting and important illustration of patronage politics in decentralized states. The federal and state governments provide several welfare programs to families identified officially as living below the poverty line. For instance, through one of the the largest welfare programs, the Targeted Public Distribution Systems (TDPS), families living below the poverty line receive essential food items at rates far below their market prices. Similarly, the federal government allocates resources to the states for other welfare programs, including pensions for poor widows and older people (National Social Assistance Programme, NSAP), scholarship for students from poor families, and financial assistances to the rural poor to build houses (Indira Awaas Yojana, IAY) and to promote employment [14]

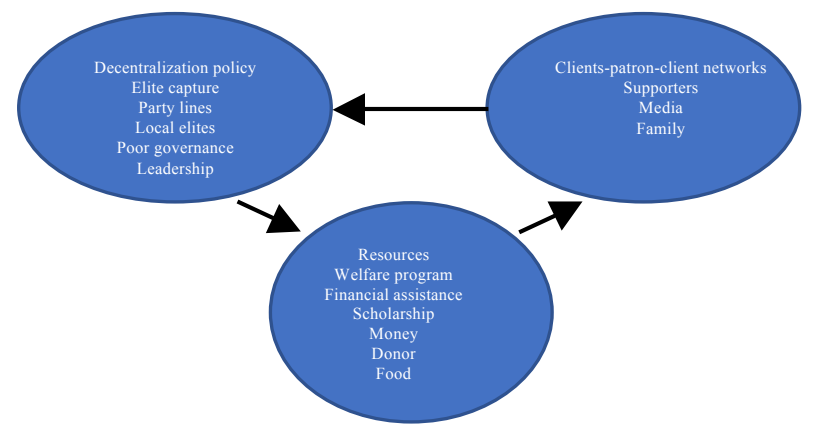

Figure 1. Political patronage leadership

Learn from Indonesia, Bangladesh, Zimbabwe and India we can get clearly understanding that is political patronage happens on all tiers: central government and local government. Zimbabwe have shown us that democratic country which has dominant power leadership tend to political patronage which use party lines to control security structures and media. Indonesia also give us lesson learn that political patronage begins from the nearest and the smallest relationship "leadership-family-money". And it happens bigger and bigger, start from family, village, and country. Bangladesh and India give us lesson learn that political patronage has political tools that are financial assistance, scholarship, donor, and food. "The relationship and political tools" emerged in order to maintain the sustainability of the political leadership or political power.

\section{B. Business Patronage Leadership}

Politics and business also have strong relationship in theoretical or practical matters. Government and private sector are the actor that influence each other in order to strengthening or weakening. Some government in decentralized developing country established by the support of the business power. Every single step of government policy needs effort and financial assistance to success the governmental policy. The performing of government and businessman relationship has potential chance to make better the people or public. It calls good governance, but if the relationship between government and businessman in order to brake the regulation and get much benefit from the people, it calls bad governance. Economics decentralization that gave large authority to the local government obliged to make good governance and good welfare from the people, not the opposite.

In Tanzania systemic clientelism with periodic effort by local elites bring in the vote, in the general absence of economic progress or state-derived benefit of any kind, sums up their political economy of agricultural policy at the local level. Initiatives justified in terms of poverty reducing or livelihoods enhancing objectives serve the purpose of networks of national and local elites [12].

Then some companies continue to burn despite the direct consequence of the haze. It identifies patronage politics as a common business culture in southeast asia. Malaysian and Singaporean investors are already familiar with patronage politics at home, they easily inserted themselves into existing patronage networks in Indonesia.

Many cases of rural resource degradation occur because centralized management regimes in African states are often de facto open access regimes and that vesting local users with rights to manage, use or own resources is therefore a key corrective. Institutional reforms are largely dependent on state authorities' patronage interests, which in turn are shaped by the relative economic value of wildlife, the degree of central control over commercial utilization, and the account of governance institutions. 'CBNRM-Community-Based Natural Resource Management' wide adoption in the context of decentralization is likely a result of multiple factors, including the growth of scholarship on common property and in political ecology during the past twenty years; the broader tenets of the neo-liberal orthodoxy of marketbased incentives, property rights, and decentralization; donor interests in achieving synergies between rural development and biodiversity conservation; and the intersection between local demands for greater control over resources and political decision makers' interests in reducing expenditures [11] 


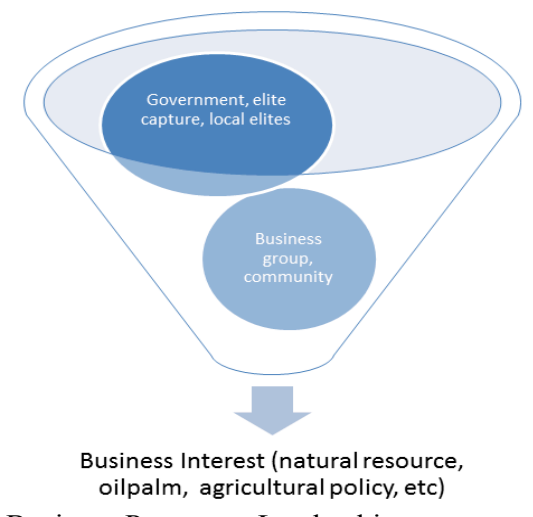

Figure 2. Business Patronage Leadership

Lesson learned from Tanzania, Indonesia, and African States we can knew that the cooperation of government and business has potential abuse of power. Some cases perform us that the people interest is left behind. The leader who have power on central government or local government can arrange and accommodate their interest in government policy. So that, government and business only prioritize their interest in order to get much and much benefit from the people by exploiting the natural resource. Business patronage leadership in decentralized developing countries often happen by agricultural policy. It is needed because there are many people interest involved in their project interest. Such as making regulation on land clearing, oil palm waste, opening company road, employing local people, etc.

\section{The Cause of Patronage Leadership}

The others aspects beside politics and government system that influence patronage leadership in developing countries are historical aspect, cultural aspects, and socio-economic aspect and also morality. The main theory that have discussed were around nature of state, governance, decentralization, social culture, and political economy. For further discussion, it needs study on leadership affair.

Patronage leadership in decentralized developing countries can't avoid, but it can minimize by strengthening the social control and law enforcement. Democracy system should ensure check and balance of the government roles. Law enforcement must be placed in the highest level, as the compliance of state.

\section{The impact of Patronage Leadership}

There are many impact of patronage leadership for the people and the state. While patronage leadership dominant the governmental affair, so that abuse of power and corruption would be easily happen. Uncontrollable patronage leadership tend weakening the democracy system. Break the law by poor governance will destruct the value and the spirit of democracy state. So that, welfare state much more far from the people expectation.

\section{CONCLUSION}

Patronage leadership in decentralized developing countries happens influenced by historical aspect, cultural aspects, and socio-economic aspect and also morality. There are two kinds: political patronage leadership and business patronage leadership. There are some actors that perform in every country: poor government, elite captures, and local elites. They also supported by their party lines and community supporter. Agricultural policy often used as tool of business patronage leadership to make smooth their business interest, between government leader and business leader.

\section{REFERENCES}

[1] R. HodderWhat's wrong with patronage?. Society, 52(2), 2015,pp. 166-173.

[2] W. Reno, W. The politics of insurgency in collapsing states. Development and Change, 33(5), 2002, pp. 837-858.

[3] P.D. Kenny. The origins of patronage politics: State Building, Centrifugalism, and Decolonization. Cambridge University Press. B.J.Pol.S. 45, 2013, pp. 141-171 doi:10.1017/S000712341300015x.

[4] P. McFadden, B.J. Taylor, A. Campbell and J. McQuilkin. Systematically identifying relevant research: Case study on child protection social workers' resilience. Research on Social Work $\begin{array}{llrr}\text { Practice, } & 22(6), & 2012, & \text { pp. }\end{array}$ http://dx.doi.org/10.1177/10497315124.

[5] G. MacDonald, G. Using systematic reviews to improve social care. London: Social Care Institute for Excellence. 2003

[6] C. Killick and B.J Taylor.. Professional decisionmaking on elder abuse: a Systematic narrative review. Journal of Elder Abuse and Neglect, 21, 2009, pp. 211-238. http://dx.doi.org/10. 1080/08946560902997421.

[7] R. Campbell, P. Pound, C. Pope, N. Britten,, R. Pill, M. Morgan et al. (2003). Evaluating meta-ethnography: A synthesis of qualitative research on lay experiences of diabetes and diabetes care. Social Science and Medicine, 56, 2003, pp.671-684.

[8] A. Lucas. Elite capture and corruption in two villages in Bengkulu Province, Sumatra. Human Ecology, 44(3), 2016, pp. 287-300. https://doi.org/10.1007/s10745-016-9837-6.

[9] A.S. Kochanek, A. Stanley. governance, patronage politics, and democratic transition in Bangladesh . Asian Survey. Vol. 4, No. 3 (May-Jun, 2000), 2009 pp. 530-550. http://www.jstor.org/stable/3021160.

[10] D. Mpondi. The Institunalization of one man rule and the politics of succesion and patronage in Zimbabwe. International Relation and Diplomacy, August 2015, Vol. 3, No.8, 2015, pp. 511-519 doi:10.17265/2328-2134/2015.08.002.

[11] A. Sadanandan. Patronage and decentralization: The politics of poverty in India. Comparative Politics, Vol. 44, No.2, (January 2012), pp. 211-228. http://www.jstor.org/stable/23211811.

[12] B. Cooksey. Politics, patronage and projects: the political economy of agricultural policy in Tanzania. The FAC Political Economy of Agricultural Policy in Africa (PEAPA)work system, 2012, pp. 12-13.

[13] H. Varkkey. Patronage politics as a driver of economic regionalisation: The Indonesian oil palm sector and transboundary haze. Asia Pacific Viewpoint 53 (3), 2012, pp. 313-328. http://onlinelibrary.wiley.com/doi/10.1111/j.14678373.2012.01493.x/abstract.

[14] F. Nelson and A. Agrawal. Patronage or participation? communitybased natural resource management reform in Sub-Saharan Africa. Development \& Change, 39 (4), 2008, pp. 557-585. https://doi.org/10.1111/j.1467-7660.2008.00496.x. 